\title{
New Books Published by Elsevier
}

DOI: $10.1134 / \mathrm{S} 1061934810100175$

Hyperspectral Imaging for Food Quality Analysis and Control, Sun, D.-W., Ed., Elsevier, 2010, 480 p.

Lindon, J. and Koppenaal, D., Encyclopedia of Spectroscopy and Spectrometry, Elsevier, 2010, 2nd ed., 3312 p.

Molecular Diagnostics: Techniques and Applications for the Clinical Laboratory, Grody, W., Nakamura, R., Kiechle, F., and Strom, C., Eds., Elsevier, 2009, 736 p.

Handbook of Methods and Instrumentation in Separation Science, Poole, C., Ed., Elsevier, 2009, vol. 1., $880 \mathrm{p}$.

Handbook of Methods and Instrumentation in Separation Science, Poole, C., Ed., Elsevier, 2009, vol. 2, $1294 \mathrm{p}$.

Zhang, S., Lu, X., Zhou, Q., Li, X., Zhang, X., and Li, S., Ionic Liquids: Physicochemical Properties, New York: Elsevier, 2009, 520 p.

Le Ru, E. and Etchegoin, P., Principles of SurfaceEnhanced Raman Spectroscopy, Elsevier, 2009, 538 p.

Advances in Flow Injection Analysis and Related Techniques, Kolev, S.D. and McKelvie, I.D., Eds., Amsterdam: Elsevier, 2009, 800 p.

Aspects of Explosives Detection, Marshall, M. and Oxley J., Eds., Elsevier, 2009, 302 p.

Frontiers of Molecular Spectroscopy, Laane, J., Ed., Elsevier, 2009, 740 p.

Molecular Characterization and Analysis of Polymers, vol. 53 of Comprehensive Analytical Chemistry, Chalmers, J. and Meier, R., Eds., Elsevier, 2009, $776 \mathrm{p}$.

Protein Mass Spectrometry, Whitelegge, J., Ed., Elsevier, 2009, 552 p.

Capillary Electrophoresis Methods for Pharmaceutical Analysis, Ahuja, S. and Jimidar, M., Eds., Academic, 2008, 546 p.
Pic, Y., Food Contaminants and Residue Analysis, vol. 51 of Comprehensive Analytical Chemistry, Elsevier, 2008, 848 p.

Todoli, J.-L. and Mermet, J.-M., Liquid Sample Introduction in ICP Spectrometry: A Practical Guide, Elsevier, 2008, 300 p.

Medical Applications of Mass Spectrometry, Vekey, K., Telekes, A., and Vertes, A., Eds., Elsevier, 2008, 606 p.

Analysis of Environmental Radionuclides, Povinec, P., Ed., Elsevier, 2008, 538 p.

UV-Visible Spectrophotometry of Water and Wastewater, vol. 27 of Techniques and Instrumentation in Analytical Chemistry, Thomas, O. and Burgess, C., Eds., Elsevier, 2007, 372 p.

Food Toxicants Analysis: Techniques, Strategies, and Developments, Pic, Y., Ed., Elsevier, 2007, 786 p.

In-situ Spectroscopic Studies of Adsorption at the Electrode and Electrocatalysis, Shi-Gang Sun, Christensen, P.A., and Wieckowski, A., Eds., Elsevier, 2007, $558 \mathrm{p}$.

Medical Applications of Mass Spectrometry, Vekey, K., Telekes, A., and Vertes, A., Eds., Elsevier, 2007, 606 p.

The Encyclopedia of Mass Spectrometry, vol. 6: Ionization Methods, Gross, M.L. and Caprioli, R.M., Eds., Elsevier, 2007, 1100 p.

Petrovic, M. and Barcelo, D., Analysis, Fate, and Removal of Pharmaceuticals in the Water Cycle, Elsevier, 2007, 600 p.

Laser-Induced Breakdown Spectroscopy, Singh, J.P. and Thakur, S.N., Eds., Elsevier, 2007, 454 p.

N. B. Zorov 